\title{
Peran Digital Marketing dalam Mendongkrak Omset bagi UMKM Emping Mlinjo di Desa Pucangan Kecamatan Kartasura Kabupaten Sukoharjo
}

\author{
Bambang Harjito*, Farah Mufidah, Laili Nur Afifah \\ Universitas Sebelas Maret, Surakarta \\ *bambang_harjito@staff.uns.ac.id
}

\begin{abstract}
Abstrak
Pucangan adalah sebuah desa yang terletak di Kecamatan Kartasura, Kabupaten Sukoharjo, Jawa Tengah. Banyak ditemukan pohon melinjo di daerah Sukoharjo sehingga tidak sedikit masyarakat Sukoharjo yang memanfaatkan biji buah melinjo sebagai olahan emping melinjo, salah satunya masyarakat di Desa Pucangan. Digital marketing sudah terbukti efektif untuk memasarkan suatu produk. Tujuan dilaksanakannya kegiatan workshop digital marketing ini adalah memberikan pengetahuan tentang pentingnya menerapkan strategi pemasaran digital serta meningkatkan industri yang ada di Desa Pucangan agar mampu bersaing seiring dengan perkembangan zaman. Metode pelaksanaan dari kegiatan ini dimulai dari mengidentifikasi potensi desa, pelibatan masyarakat, hasil dan evaluasi kegiatan, dan pelaksanaan program kerja. Hasil dari kegiatan ini adalah peserta memperoleh pengetahuan peran digital marketing terutama konsep dan strategi pemasaran online mulai dari packaging, foto produk, pemberikan identitas produk yang lengkap, dan pengembangan inovasi produk.
\end{abstract}

\section{Kata kunci : Desa Pucangan, Digital marketing, Emping melinjo}

\section{Pendahuluan}

Pucangan adalah sebuah desa yang terletak di Kecamatan Kartasura, Kabupaten Sukoharjo, Jawa Tengah. Desa Pucangan berbatasan dengan Kabupaten Boyolali, Kecamatan Colomadu Kabupaten Karanganyar, dan Kabupaten Klaten. Oleh sebab itu dapat dikatakan Desa Pucangan merupakan desa yang paling pojok bagian barat di Kabupaten Sukoharjo. Kabupaten Sukoharjo sebagian masyarakatnya masih berprofesi sebagai petani. Kondisi ini juga menjadi faktor banyak ditemukan pohon melinjo di Kabupaten Sukoharjo. Sehingga, banyak masyarakat yang memanfaatkan biji buah melinjo sebagai olahan emping melinjo. Salah satu daerah yang memanfaatkan biji buah melinjo sebagai sumber penghasilan adalah daerah Dusun Tojayan RT.01/RW.04, Desa Pucangan. Oleh karena itu, Desa Pucangan memiliki potensi besar di industri kecil emping mlinjo.

Digital marketing atau pemasaran melalui e-commerce memiliki banyak manfaat terhadap industri usaha mikro, kecil, dan menengah (UMKM) dengan memperluas peluang perusahaan di pasar, meningkatkan penjualan, meningkatkan komunikasi, meningkatkan citra perusahaan, mempercepat proses, dan meningkatkan produktivitas karyawan (Rahayu dan Day, 2017). Digital marketing sudah terbukti efektif untuk memasarkan suatu produk terlebih dengan adanya kasus corona virus yang menyebabkan perusahaan-perusahaan mendorong karyawan untuk bekerja dari rumah dan masyarakat menolak untuk pergi ke tempat umum atau berkerumun Kementerian Komunikasi dan Informatika (2020) mencatat, penjualan produk di media sosial dan e-commerce melonjak $400 \%$ per April 2020.

Dikutip dari Solopos kamis, 25 Juni 2020 bahwa Kabupaten Sukoharjo sedang gencar memberikan bimbingan teknis (Bintek) pemasaran secara online dalam rangka penerapan tatanan kenormalan baru atau new normal. Kepala Dinas Perdagangan Koperasi dan Usaha Kecil Menengah (Disdagkop) UKM Sukoharjo, Sutarmo, menargetkan bintek dilakukan agar pelaku UMKM tetap menjalankan usaha dan memasarkan secara online di tengah pandemi Covid-19. (Wardani, I. S, 2020 )

Penelitian mengenai digital marketing sudah dilakukan oleh (Hapsoro dkk, 2019) yang menghasilkan bahwa penelitian tersebut terjadi peningkatan pemahaman mengenai materi resolusi konflik yang dibuktikan dengan 
lebih dari 70\% peserta mengerti akan materi yang disampaikan. Penelitian serupa dilakukan oleh (Dwijayanti dan Pramesti ,2020) yang menghasilkan UMKM pempek4beradek memiliki berbagai macam pemasaran digital $e$ commerce dengan membuat platform online seperti website, facebook, instagram dan market place (shoppe, lazada, dan tokopedia).

Salah satu tugas sebagai anggota civitas akademika dalam Tri Dharma Perguruan Tinggi, tim Kuliah Kerja Nyata (KKN) Desa Pucangan terpanggil untuk ikut serta dalam pembangunan ekonomi di desa tersebut. Dengan adanya latar belakang tersebut, tim KKN Desa Pucangan merasa tertarik untuk turut serta berperan aktif dalam mengupayakan pengembangan potensi tersebut melalui workshop digital marketing agar industri yang ada di Desa Pucangan khususnya di Tojayan dapat berkembang dan mampu bersaing seiring dengan perkembangan zaman.

\section{Metode Pelaksanaan}

Kegiatan workshop digital marketing dilaksanakan secara tatap muka pada tanggal 21 Februari 2021 dengan tetap menjaga protokol kesehatan seperti, memakai masker, mencuci tangan, dan menjaga jarak.

Menyadari besarnya potensi desa dan mempertimbangkan permasalahan yang menghambat potensi desa maka, diperlukan adanya kegiatan pelatihan yang mampu untuk memecahkan masalah tersebut. Workshop digital marketing berlangsung selama 90 menit dengan rincian waktu 60 menit diberikan materi teori, 15 menit kemudian untuk sesi tanya jawab, dan 15 menit terakhir digunakan sebagai praktik dari materi teori yang telah disampaikan di depan.

Metode pelaksanaan kegiatan ditunjukkan dalam Gambar 1, kegiatan pengabdian diawali dengan mengidentifikasi potensi daerah yang ada. Sektor ekonomi pemasaran emping menjadi tema yang diambil oleh Tim KKN karena mempunyai efek samping yang besar bagi perekonomian warga dusun Tojayan, desa Pucangan. Tahapan Kedua adalah pelibatan masyarakat, karena kurangnya pengetahuan dan pemahaman warga dusun Tojayan desa Pucangan mengenai pentingnya digital marketing bagi usaha mereka. Pelibatan masyarakat terutama pemuda atau calon pelaku usaha menjadi sangat penting kedepannya, karena sesuai dengan perkembangan teknologi dalam mempromosikan emping di desa Tojayan desa Pucangan.

Tahapan Ketiga yaitu pelaksanaan kegiatan, kegiatan yang dipilih yaitu workshop digital marketing. Tujuan dari kegiatan ini adalah memberikan pengetahuan tentang pentingnya menerapkan strategi pemasaran digital, yang di desain khusus untuk meningkatkan omset penjualan, mulai dari packaging yang menyertakan semua informasi yang dibutuhkan oleh konsumen, packaging yang menarik perhatian konsumen, cara pemasaran emping melinjo agar dapat memperluas pasar, dalam digital marketing hal yang paling berpengaruh adalah foto/video produk yang ingin dipasarkan dalam hal ini emping melinjo, pemilihan harga juga menjadi penting dalam digital marketing.

Tahapan Keempat adalah Hasil dan Evaluasi Kegiatan, Evaluasi dilakukan dengan menggali potensi kemampuan peserta dalam hal membuat foto/video produk emping melinjo agar dapat bersaing dalam mempromosikan dan memasarkan produk secara digital.

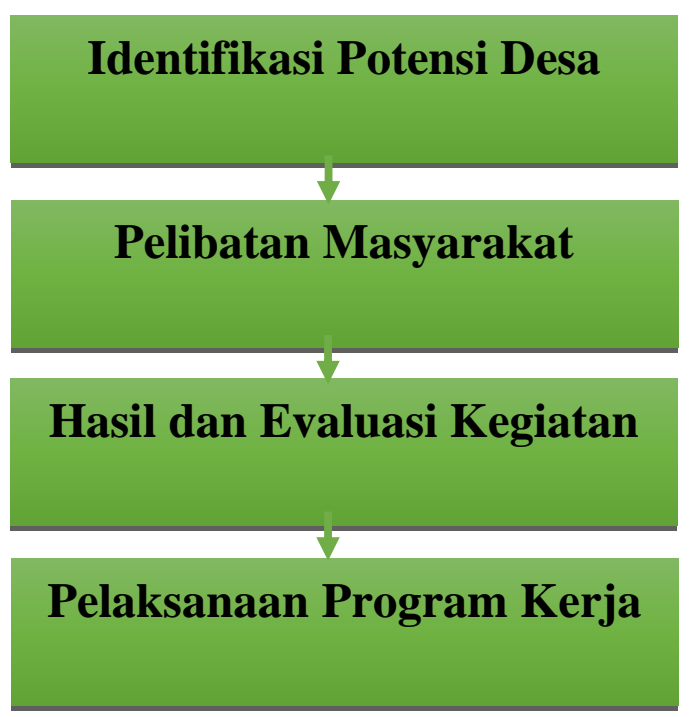

Gambar 1. Metode Pelaksanaan 


\section{Hasil dan Pembahasan}

\section{Proses Pelatihan}

Peserta pelatihan diberikan materi mengenai cara memasarkan di pasar online. Materi diberikan judul "Memanfaatkan Era Digi-Net untuk Dongkrak Omset". Dijelaskan pula tujuan dari penjualan melalui pasar online yaitu memudahkan komunikasi dengan konsumen dan memperluas pangsa pasar. Dalam kegiatan ini, peserta diberikan beberapa tips untuk menjadikan produk emping melinjo biasa menjadi istimewa yaitu dengan memberikan packaging yang mempunyai ciri khas dan terlihat premium. Kemudian, dalam hal foto produk juga penting, memberikan kesan menarik pada produk. Pada kemasan produk diberikan identitas produk dengan lengkap mulai komposisi, izin edar, hingga masa expired produk. Tidak hanya sampai produk yang ada sekarang, peserta diajak untuk berpikir inovasi masing-masing produk. Inovasi dicari dengan tahapan yang pertama, mencari tahu masalah kepada pembeli terkait produk yang sudah ada, kemudian mengamati pesaing, dan yang terakhir membuat hal yang berbeda pada produk.

Setelah diberikan teori, selanjutnya peserta diajak untuk mempraktikkan teori yang telah disampaikan yaitu dengan mengambil gambar produk layaknya foto studio pada produk dengan memanfaatkan benda di sekitarnya. Setelah mengambil gambar foto produk, dilakukan praktik packaging pada produk agar produk menjadi lebih menarik dan terlihat premium.

\section{Hasil Kegiatan}

Setelah dilaksanakan pelatihan secara luring, beberapa capaian atau hasil dari pelaksanaan kegiatan pengabdian masyarakat diantaranya :

1) Sebanyak 20 warga masyarakat Dusun Tojayan, Desa Pucangan serta 9 mahasiswa KKN mengikuti workshop digital marketing dalam rangka pemberdayaan masyarakat desa berbasis digital. Kegiatan workshop digital marketing ditunjukkan pada Gambar 2.

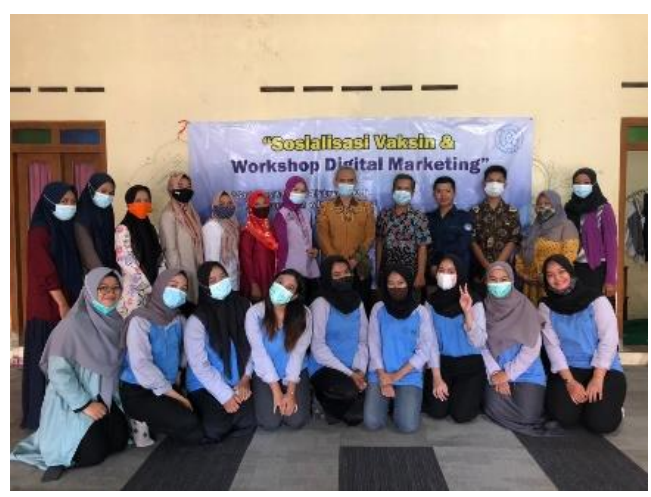

Gambar 2. Kegiatan Workshop Digital Marketing

2) Para warga tersebut sangat antusias dan tertarik mengikuti pelatihan digital marketing yang diselenggarakan oleh Tim KKN Desa Pucangan. Dibuktikan dengan banyaknya tanya jawab seputar digital marketing dan antusiasme dalam mempraktikkan materi. Sesi Tanya jawab ditunjukkan pada Gambar 3.

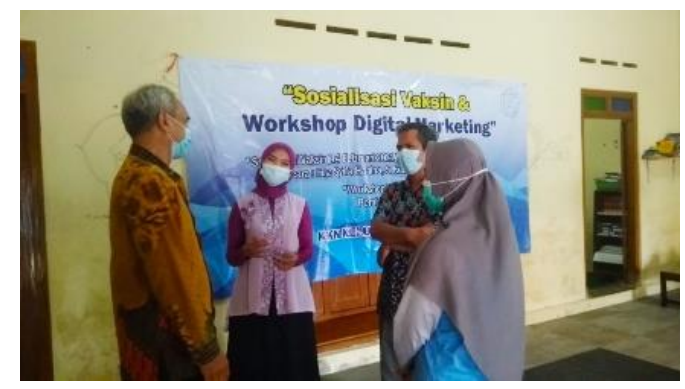

Gambar 3. Sesi Tanya Jawab 
3) Peserta telah memperoleh pengetahuan peran digital marketing terutama konsep dan strategi pemasaran online mulai dari packaging, foto produk, pemberikan identitas produk yang lengkap, dan pengembangan inovasi produk. Hasil foto produk oleh peserta ditunjukka pada Gambar 4.

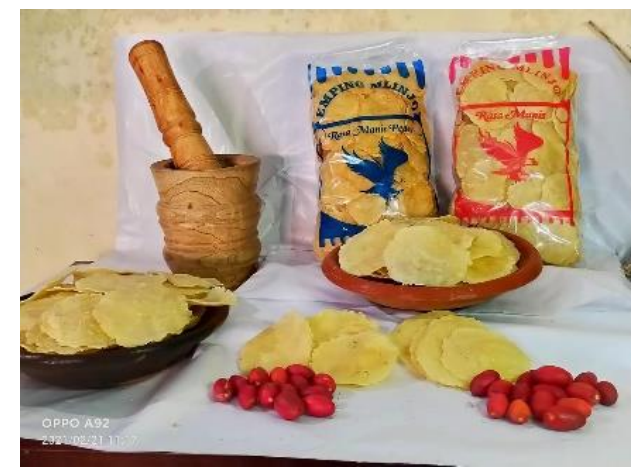

Gambar 4. Hasil Praktek Foto Produk

\section{Kesimpulan}

Dari kegiatan yang telah dilakukan oleh tim KKN Desa Pucangan dapat ditarik kesimpulan yaitu, pelaksanaan kegiatan workshop digital marketing berjalan dengan lancar dan sesuai dengan program yang direncanakan. Peserta mengalami peningkatan pemahaman mengenai peran digital marketing terutama konsep dan strategi pemasaran online mulai dari packaging, foto produk, pemberikan identitas produk yang lengkap, dan pengembangan inovasi produk dilihat dari antuasiasme dalam mengikuti workshop, banyaknya pertanyaan yang diajukan, dan dapat mempraktikkan hasil dari materi yang disampaikan. Selain itu, peserta mengaku kerap menemukan permasalahan dalam penjualan mereka salah satunya yaitu peserta sudah nyaman dengan ritme penjualan melalui cara tradisional sehingga tidak berusaha untuk memperluas pasar dengan pemasaran digital, kurangnya pengetahuan mengenai teknologi informasi, dan kesulitan dalam mengembangkan ide dari produk mereka.

\section{Daftar Pustaka}

Burhan, F. A. (2020, Oktober 13). Transaksi E-Commerce Naik 400\%, Kominfo Latih 2.500 UMKM Jualan Online. Retrieved from kominfo: https://kominfo.go.id/content/detail/30110/transaksi-e-commerce-naik400-kominfo-latih-2500-umkm-jualan-online/0/sorotan_media

Dwijayanti, A., \& Pramesti, P. (2020). Pemanfaatan Strategi Pemasaran Digital menggunakan E-Commerce dalam mempertahankan Bisnis UMKM Pempek4Beradek di masa Pandemi Covid-19. IKRAITH-ABDIMAS, Vol 4 No 2.

Hapsoro, B. B., Palupiningdyah, \& Slamet, A. (2019). Peran Digital Marketing sebagai Upaya Peningkatan Omset Penjualan Bagi Klaster UMKM di Kota Semarang. ABDIMAS 23 (2), 117-120.

Mulyani, W. (2020). EDUKASI COVID-19 MELALUI PROGRAM KKN UNS UNTUK MEWUJUDKAN DESA KEDUNGWINANGUN SIGAP, CERDAS DAN SEHAT. Junal Penelitian dan Pengabdian Masyarakat, 1.

Prasetya, B. A. (2021). Gandeng Pelaku Usaha Emping Melinjo Tim KKN UNS Adakan Workshop Digital Marketing. Surakarta: Humas UNS.

Rahayu, R., \& Day, J. (2017). E-commerce adoption by SMEs in developing countries: evidence from Indonesia. Eurasian Bus Rev, 7.25-41.

Saputra, R., Lusi Nur Ardhiani, L. N., \& Setiadi, A. (2020). Digital Marketing sebagai Upaya Pemberdayaan Masyarakat di Kabupaten Batang. semnasppm, 352-356.

Wardani, I. S. (2020, Juni 25). New Normal, UMKM Sukoharjo Digenjot Pemasaran Online. Retrieved from Solopos: https://www.solopos.com/new-normal-umkm-sukoharjo-digenjot-pemasaran-online-1067409 